\title{
Postglacial morpholineaments as an indicator of ice sheet dynamics during the Saale Glaciation in the Białystok Plateau and Sokółka Hills (NE Poland)
}

\author{
Joanna RYCHEL ${ }^{1, *}$ and Marcin MORAWSKI ${ }^{2}$ \\ 1 Polish Geological Institute - National Research Institute, Rakowiecka 4, 00-975 Warszawa, Poland \\ 2 l'immeuble SarSaara Lot 124B-2 Yoff Toundoup Rya, Dakar, Senegal
}

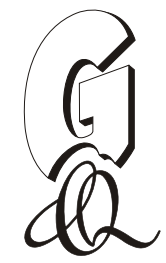

Rychel, J., Morawski, M., 2017. Postglacial morpholineaments as an indicator of ice sheet dynamics during the Saale Glaciation in the Białystok Plateau and Sokółka Hills (NE Poland). Geological Quarterly, 61 (2): 334-349, doi: 10.7306/gq.1352

The palaeogeographical reconstruction of the deglaciation process in NE Poland during the Odranian Glaciation Wartanian Stadial (Saale MIS 6) is based mainly on the analysis of glacial morpholineaments, performed using the GIS programs that provide us with better understanding of the glacial landscape evolution, spatial reconstruction of glacial processes, and postglacial landscape development. Analysis of postglacial morpholineaments was carried out based on the Digital Elevation Model (DEM) as well as geological, geomorphological and topographic maps. It resulted in the delimitation of visible linear postglacial landforms, their identification and classification, and the determination of their genetic and chronological relations. Directions of the lineaments were determined through quantitative analysis. Qualitative analysis was applied to determine the spatial and temporal sequence of events, directions of ice movement and its range. Two glacial lobes, Biebrza and Neman, existed in the north-western part of the Białystok Plateau and Sokółka Hills during the last glacial advance. The lobed nature of the ice sheet can be confirmed by field data collected from, e.g., sites in Knyszewicze, and by topographic analysis of Quaternary sediments, combined with their thickness and genesis. The obtained reconstruction of the last glacial advance and retreat in the study area can be used in further regional discussions on the character and dynamics of the last glaciation in this region.

Key words: morpholineament, Saalian ice sheet movement, lobe, NE Poland.

\section{INTRODUCTION}

Morphological linear elements of the relief, more and more easily detectable through the use of digital data on the land surface (satellite and aerial images, digital terrain and elevation models - DTM and DEM), have long attracted the attention of researchers. Their origin has been associated primarily with the deep geological structure of a given area as a structural foundation of the land relief (cf. Tirén and Beckholmen, 1989; Graniczny, 1989; Graniczny et al., 1995; Gabrielsen et al., 2002). In areas covered by Pleistocene glaciations and contemporarily glaciated, a correlation is observed between linear morphological elements and the activity of ice sheets (e.g., Boulton and Clark, 1990; Clark, 1993, 1997; Fahnestock et al., 1993; Punkari, 1995a, b; Bindschadler and Vornberger, 1998; Boulton et al., 2001; Morawski, 2009a, b). Attempts have been made to reconstruct ice sheet movement directions based on selected, positive and negative linear glacial morphological forms, such as mega-scale glacial lineations (e.g., Stokes and Clark, 2001, 2002; Przybylski, 2008; King et al., 2016), drumlins (e.g., Benn

\footnotetext{
* Corresponding author, e-mail: joanna.rychel@pgi.gov.pl Received: March 3, 2016; accepted: October 14, 2016; first published online: March 20, 2017
}

and Evans, 2010; Lamsters, 2012) crevasses (Morawski, 2005), frontal moraines (Kalm, 2012) or subglacial channels and kame plateaux (Bitinas, 2012). They are referred to as glacial morpholineaments (Morawski, 2005) or glacial lineations (cf. Kleman and Borgstrom, 1996) and used to reconstruct the direction of ice flow and ice sheet movement.

In the context of glacial geomorphology and its development, it appears necessary to use GIS to integrate and analyse morphological data obtained from various sources, and to investigate spatial relationships between particular elements of the postglacial landscape for further temporal reconstruction of its evolution (Napieralski et al., 2007). Landforms presented on the map may represent phenomena and processes of diverse age. Digital data interpretation in the GIS environment was conducted to identify them as morpholineaments and divide into groups and layers (Napieralski et al., 2007). Analysis of the relationships between morpholineaments allows for reversing the sequence of events, i.e. for developing an inverted relief model which presents the sequence of glacial events and gives insight into the ice sheet (or its parts) dynamics in both time and space (cf. Greenwood and Clark, 2009a, b; Stokes et al., 2009; Evans et al., 2014).

However, so far the application of GIS and DEM in the reconstruction of the direction of Pleistocene ice sheet advance is restricted to areas glaciated during the Vistulian Glaciation. These areas are characterized by a fresh relief, unchanged or transformed only to a small degree by post-sedimentary pro- 
cesses. Due to this, the identification of particular forms does not raise any problems. On the contrary, the morphology of areas beyond the range of the LGM and glaciated during older ice-sheet advances could have undergone deep transformation both in the interglacial periods and in periglacial conditions of younger glaciations. Such transformation included reorganization of the river network (Kasse, 1997; Kasse et al., 2003; Rychel et al., 2015; Woronko et al., 2016), and activation of slope (Dylik, 1953; Dzieduszyńska et al., 2014) and aeolian processes (Kasse, 1997; Zeeberg, 1998; Renssen et al., 2007; Zieliński et al., 2016). The Sokółka Hills (NE Poland) and the Grodno Plateau (E Belarus) are examples of such areas. They were glaciated during MIS 6, were twice under the influence of periglacial climate during the MIS 6 and the Vistulian ice-sheet retreats (Gilewska, 1991), and twice under the influence of processes during warmer, interglacial periods (MIS 5e and MIS 1). Therefore, the reconstruction of the directions at which the ice-sheet advanced in areas with the landscape shaped during older glaciations requires the application of multistage morpholineament analysis (MMA), in contrast to the previously conducted glacial morpholineament analysis (GMA) (e.g., Mora- wski, 2005; Ewertowski and Rzeszewski, 2006; Przybylski, 2008; Szuman et al., 2013; King et al., 2016).

The MMA provides a basis for a hypothesis of the predominant lobe style of glaciation and former ice sheet dynamics in the region that needs to be checked in a broader area.

The analysis was aimed at the reconstruction of:

- directions of ice sheet advance of the Odranian Glaciation, Wartanian Stadial, in the boundary zone between NE Poland and Belarus;

- ice sheet dynamics;

- functioning of the Biebrza lobe (NE Poland) and Neman lobe (W Belarus) in time and space.

\section{GEOLOGICAL SETTING}

The study area is located in northeastern Poland and includes the Sokółka Hills (excluding their southeastern limits), the northwestern part of the Białystok Glacial Plateau (Kondracki, 2009), and the western part of the Grodno Plateau,

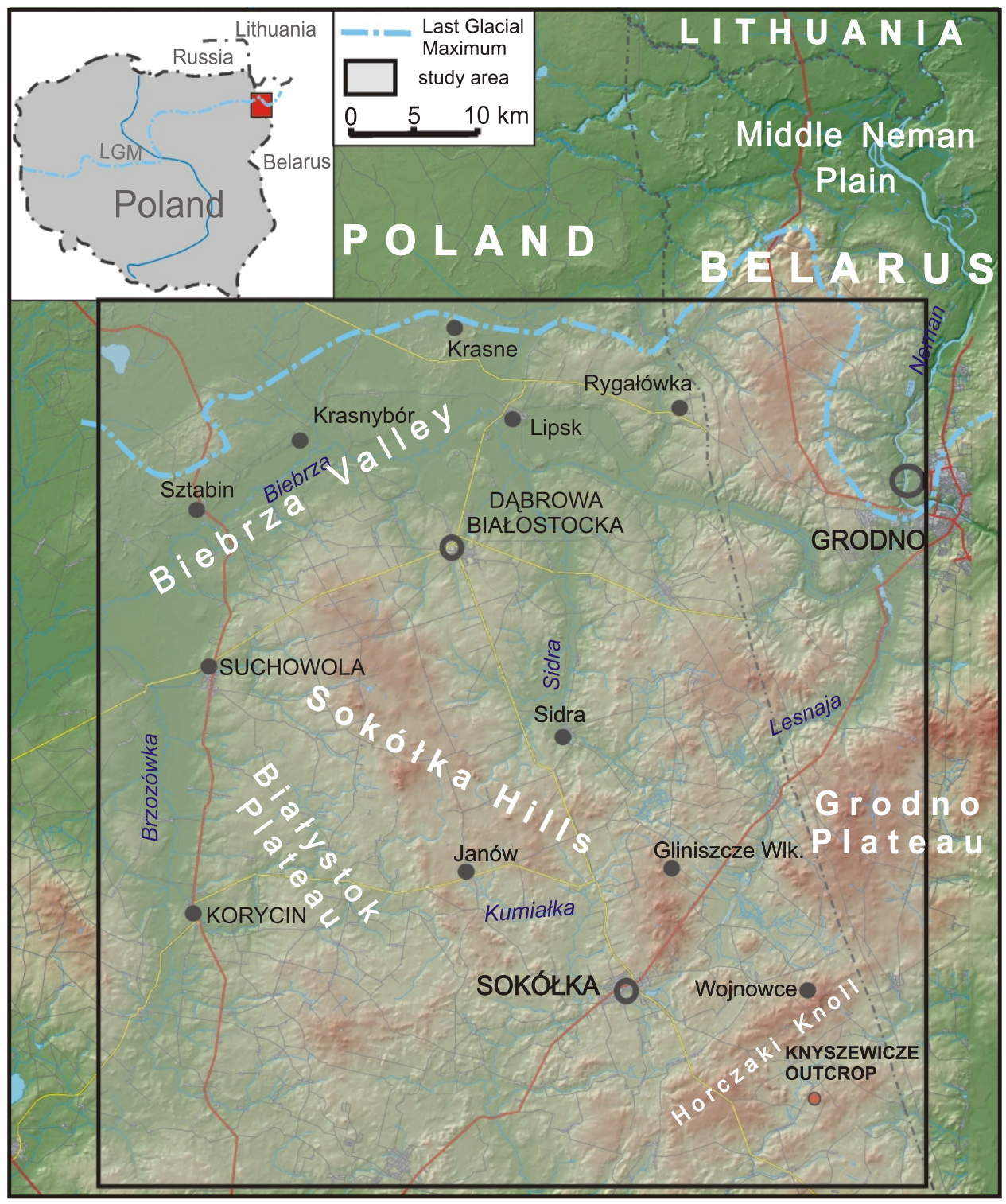

Fig. 1. Location of the study area 
Belarus (Fig. 1). The area is more than $2,500 \mathrm{~km}^{2}$ in size and extends to the south of the maximum range of the Vistulian Glaciation - Last Glacial Maximum (LGM). It is one of the northernmost upland areas, formed during the retreat of the last continental glacier of the Middle Polish Glaciation (MIS 6) (Karabanov, 1987; Marks and Karabanov, 2011). The area represents an old-glacial landscape. The relief is characterized by considerable variations (>100 m) and expressive glacial landforms, e.g. glacial plateaux, sandurs, kames and end moraines (Fig. 2). The highest elevations are observed in the end moreaines of the Sokółka Hills, near the village of Gliniszcze Wielkie 236.6 m a.s.l., and on Horczaki Knoll (hump) near the village of Wojnowice $-\sim 226.3 \mathrm{~m}$ a.s.l. The lowest elevations are noted in the bottoms of river valleys southwest of Janów, i.e. the Kumiałka River - 136.6 m a.s.I. and the Sidra River (north of the village of Sidra) $-129.5 \mathrm{~m}$ a.s.I.

A characteristic element of the landscape in the area is long dry valleys with numerous side valleys, and abundant landlocked depressions adjacent to high hills (Rychel et al., 2012). The older basement played a significant role in shaping the landscape of the area (e.g., the Horczaki Knoll; Karabanov, 1987; Boratyn, 2006; Rychel et al., 2015).

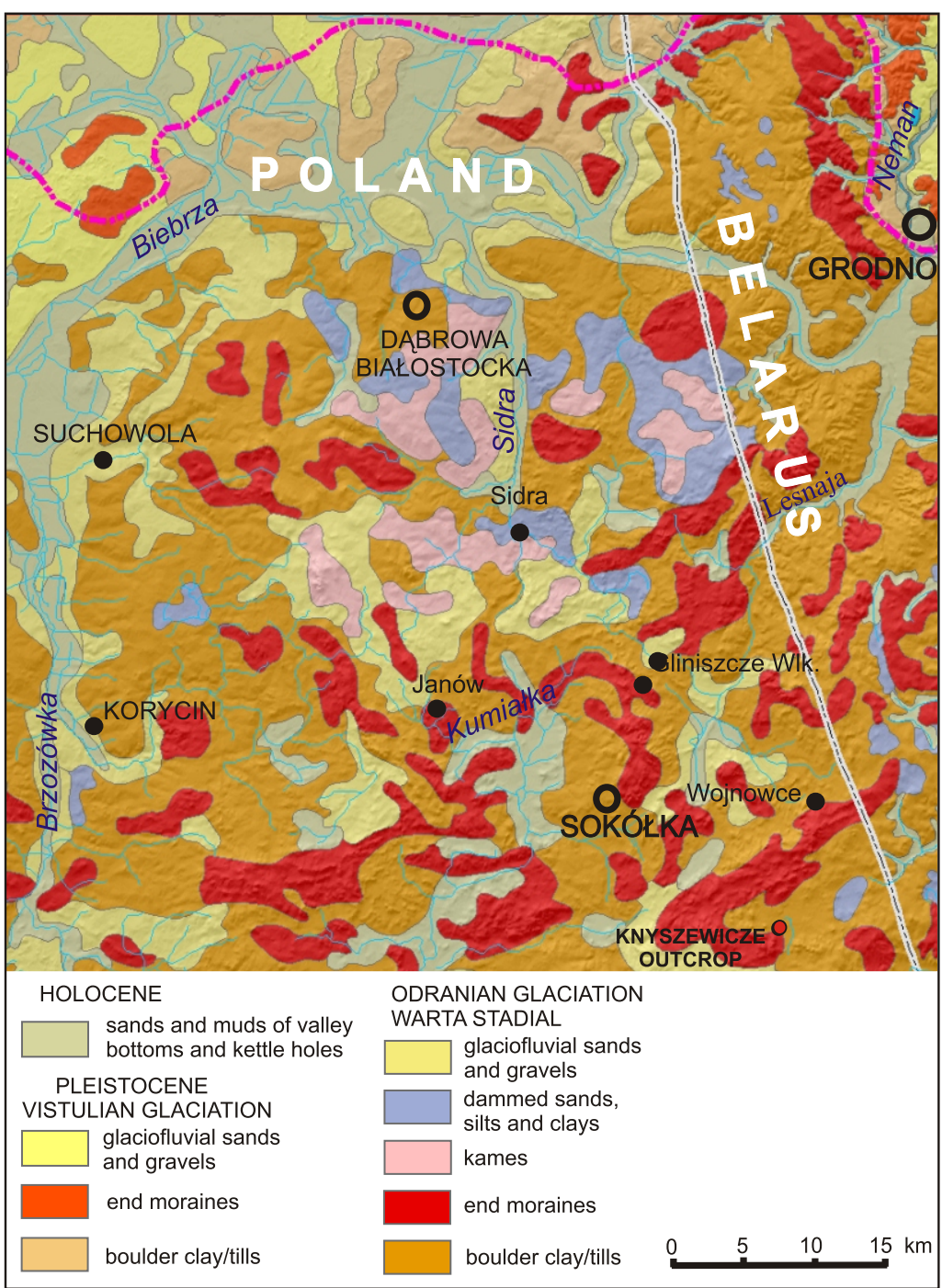

Fig. 2. Geological map of the study area (after Marks et al., 2006, changed)
According to Karabanov (1987) and Ber et al. (2012), the ice sheet of the Wartanian Stadial in the area advanced from different directions corresponding to two lobes. Ber et al. (2012) distinguished the Biebrza lobe, which advanced from the NW to the SE, and the Neman lobe, with a general NE-SW orientation. Banaszuk (2010) described the presence of a Middle Vistulian (Świecie Stadial - MIS 4) ice sheet in the North Podlasie Lowland. This concept was confirmed by the authors of the Detailed Geological Map of Poland (DGMP) (e.g., Sztabin sheet - Kacprzak and Lisicki, 2007; Dąbrowa Białostocka sheet - Wrotek, 2009)

\section{METHODS}

The analysis of the Sokółka Hills and the Białystok and Grodno Plateaus (Fig. 3) was conducted using nine sheets of the Detailed Geological Map of Poland (scale 1:50,000) located in NE Poland (Krzywicki, 2005; Boratyn, 2006; Kmieciak, 2006; Kozłowski, 2006; Kacprzak and Lisicki, 2007; Majewska, 2008a, b; Płonczyński et al., 2009; Wrotek, 2009) and the central and southern part of the Geological Map of the northern borderland between Poland and Belarus at the scale of 1:250,000 near Sokółka and Grodno (Marks and Karabanov, 2011).

The morpholineaments were determined on the basis of surface geological data, the digital elevation model, and the topographic map at the scale of $1: 10,000$ and $1: 25,000$. An exaggerated DTED 2 terrain model, rectified to the PUWG "92" projection, and a coordinates system (State Geodetic Coordinate System "92") with the spatial resolution of the raster cell of 30 $\mathrm{m}$ was used in shaded, coloured and greyscale layouts. The topographic map of Poland was visualized in the WMS service from the servers of geoportal.gov.pl.

The multistage morpholineament analysis (MMA) was conducted in subsequent stages. Landforms related to the following processes were distinguished:

- ice sheet advance: subglacial channels, terminal basins (Fig. 4A);

- stabilization of the ice sheet front, including positive (end moraines, eskers, proximal parts and edges of outwash plains) and negative landforms (subglacial channels; Fig. 4B);

- ice sheet retreat, including negative (kettle holes) and positive landforms (crevasses, kames, hummocky moraines; Fig. 4C);

- interglacials (river valleys; Fig. 4D).

The available elevation and geological data enabled the identification of glacial morpholineaments and permitted their geomorphological classification into individual genetic groups. Visual analysis of elevation and geological data was used to identify morphological lines within the glacial forms (ridges) and the longer axis of the landform outline. Eight different positive and negative genetic groups of landforms were distinguished, directly or indirectly related to the glacial environment (Fig. 4 and Table 1) 


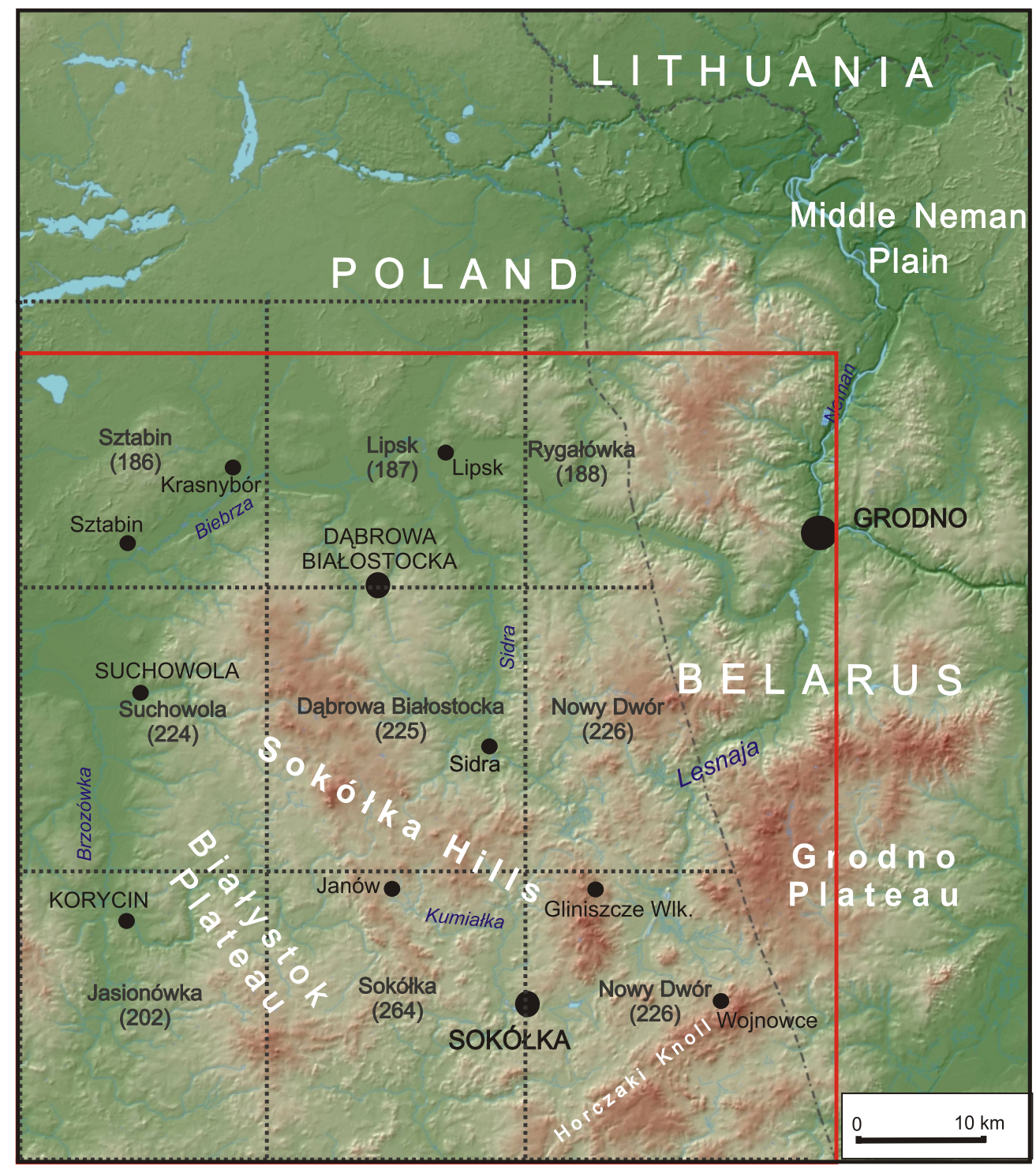

Fig. 3. List of DGMP sheets in the study area

Most of them were landforms of direct glacial or glaciofluvial origin. Positive forms included: crevasse accumulation forms and eskers, moraine hills, proximal parts and edges of outwash plains (sandurs) and fans, kame hills, and ridges of hummocky terrain/moraines, whereas negative landforms were represented by subglacial channels and terminal basins. In addition, landlocked depressions - kettle holes (pits and depressions within glacial plateaux) as well as flat-bedded dry valleys (gullies) and small river valleys, whose existence had no direct connection with the ice-sheet activity, were also distinguished. The aim of distinguishing the two last groups of landforms was the assumption that their location and orientation were inherited after the former ice-sheet configuration (e.g., varying thickness, pattern of cracks/joints), which might have had a relationship with the stress field during the glaciation.

The terminal basin (vast depressions of the upland surface that stretch over several kilometres) are hollows that originated in consequence of stress exerted against the basement under compression-tension conditions of a regional stress field that developed during the ice sheet transgression as a result of its progressive movement (cf. Nye, 1952 after Jania, 1997; Patterson, 1994). When viewed in plan, they form a low-angle joint system of the morpholineaments, where the bisector of the obtuse angle between both maxima may be identified as being identical with the resultant direction of the ice flow (Fig. 4) - the main driving stress vector.

The arrangement of subglacial channels reflects the system of channelled subglacial drainage (cf. Kehew et al., 2012), whose development is (in general) concordant with the driving stress vector within individual ice sheet sectors. The orientation resultant (average vector), determined from the orientation of these glacial forms, may render the direction of ice advance (Fig. 4). Being of glacial origin, these landforms directly indicate the direction of ice sheet advance (Majdanowski, 1950; Galon, 1972). The presence of subglacial channels and terminal basins in the analysed area was assumed to be the only subglacial system landforms whose arrangement directly reflects the direction of ice sheet advance and dynamics.

Crevasse accumulation forms, eskers, moraine hills, kames, proximal parts and edges of outwash plains (sandurs) and fans represent elements of the marginal zones, the distribution and arrangement of which indicate subsequent phases of ice sheet stagnation (Bitinas, 2012; Morawski, 2015). Moraine hills of various origins, hummocks, pits and depressions are com- 


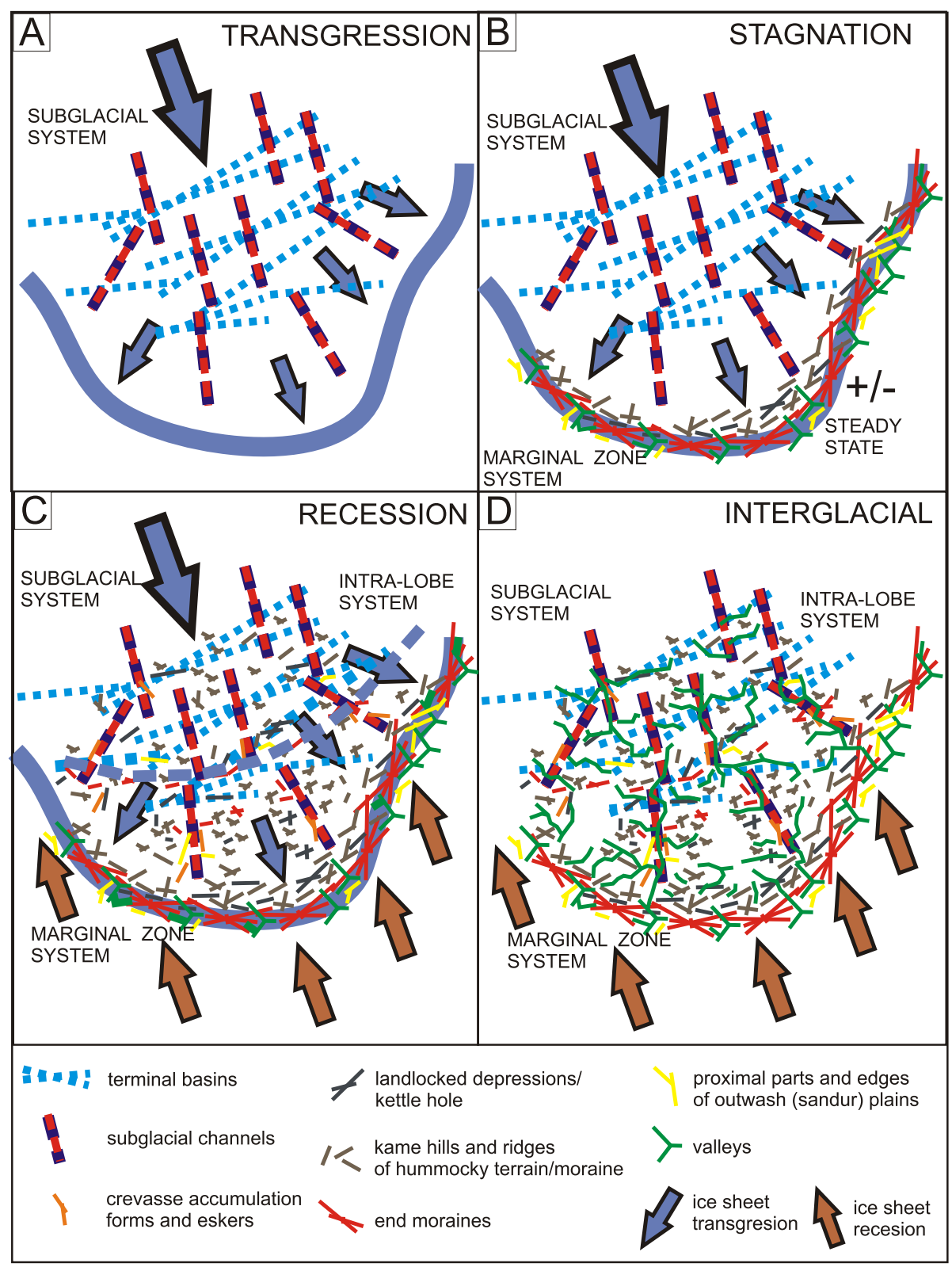

Fig. 4. Model of post-glacial morpholineaments formation, its sequence and pattern within an idealized ice sheet lobe with dominant frontal deglaciation

mon elements of the relief of glacial plateaux. Based on their elongated shape, orientation and concentration, indirect conclusions may be drawn about the dynamics of the deglaciation process in the study area. The orientation and distribution of zones of marginal and intra-lobe landforms reflect local stress systems within the marginal parts of the ice sheet. On a regional scale (between a dozen to several tens of square kilometres), the spatial arrangement of these morpholineaments is bidirectional, which may be related to a lobe formed in the distal zones of particular channelized ice flows - palaeo-ice stream (cf. Patterson, 1997; Kasprzak, 2003; Turkowska, 2006; Jennings, 2006). In the study area, the ice-flow direction may be identical with the direction of the mid-perpendicular to the chord connecting the maxima of morpholineament sets in the marginal and intra-lobe landform systems.
Valleys are among the most distinctive elements of the present-day landscape of the Polish Lowlands. They were distinguished on the basis of the assumption of their indirect relationship with post-glacial foundations of the valley network development in the study area (Brykczyński, 1986). Landforms, classified as morpholineaments, were grouped in a vector database according to their geomorphological category.

The study area was subdivided into 20 sectors (Fig. 5A). Their size varies from $12 \mathrm{~km}^{2}$ to ca. $\sim 300 \mathrm{~km}^{2}$, and they were classified as inter-lobe (moraine junction - MJ) and intra-lobe zones (L) (Fig. 5B). Next, a sequential analysis of the spatial arrangement of morpholineaments was performed in the distinguished sectors. Collective quantitative analysis of their orientation was made by plotting various rose diagrams of the morpholineaments orientation (example in Fig. 5C.1-C.3). Quantitative 
The resultant directions of ice flow by genetic groups of morpholineaments in the sectors, and the proposed sequence of glacial events

\begin{tabular}{|c|c|c|c|c|c|c|}
\hline \multirow{3}{*}{ Sector } & \multicolumn{6}{|c|}{ RESULTANT DIRECTION ICE-MASSES FLOW [in degrees] } \\
\hline & $\begin{array}{c}\text { Terminal } \\
\text { basins }\end{array}$ & $\begin{array}{l}\text { Subglacial } \\
\text { channels } 1\end{array}$ & $\begin{array}{l}\text { Subglacial } \\
\text { channels } 2\end{array}$ & $\begin{array}{l}\text { Marginal } \\
\text { system } 1\end{array}$ & $\begin{array}{l}\text { Marginal } \\
\text { system } 2\end{array}$ & Succession \\
\hline & 1 & 2 & 3 & 4 & 5 & older $\rightarrow$ younger $(\mathrm{D} 1 \rightarrow \mathrm{D} 5)$ \\
\hline L1 & 2 & & & 346 & 23 & $1 \rightarrow 4 \rightarrow 5$ \\
\hline L2 & 2 & & & 344 & & $2 \rightarrow 4$ \\
\hline L3 & 1 & 294 & & 353 & & $1 \rightarrow 2 \rightarrow \rightarrow 4$ \\
\hline L4 & 3 & 335 & & 355 & & $1 \rightarrow 2 \rightarrow 4$ \\
\hline L5 & 5 & & & 347 & & $1 \rightarrow \rightarrow \rightarrow 4$ \\
\hline L6 & 8 & 292 & 36 & 340 & 31 & $1 \rightarrow 2 \rightarrow 4 \rightarrow 3 \rightarrow 5$ \\
\hline L7 & 10 & 40 & & 338 & 40 & $1 \rightarrow 2 \rightarrow 4 \rightarrow 5$ \\
\hline L8 & 3 & 345 & & 359 & & $1 \rightarrow 2 \rightarrow 4$ \\
\hline L9 & 2 & 287 & & 352 & & $1 \rightarrow 2 \rightarrow 4$ \\
\hline L10 & $14 ?$ & $4 ?$ & & 0 & & $1 \rightarrow 2 \rightarrow 4$ \\
\hline L11 & $353 ?$ & $282 ?$ & & 352 & & 4 \\
\hline L12 & 4 & 332 & 45 & 355 & & $\begin{array}{c}1 \rightarrow 2 \rightarrow 4 \text { for } W \text { part } \\
1 \rightarrow 2 \rightarrow 3 \rightarrow 4 \text { for NE part }\end{array}$ \\
\hline L13 & & $317 ?$ & & 3 & & 4 \\
\hline L14 & $5 ?$ & $5 ?$ & & 354 & & $1+2 \rightarrow 4$ \\
\hline L15 & & & & 355 & & 4 \\
\hline MJ1 & & & & 355 & 45 & $4 \rightarrow 5$ \\
\hline MJ2 & & & & 345 & 8 & $5=4$ \\
\hline MJ3 & & & & 325 & 25 & $5=4$ \\
\hline MJ4 & & & & 350 & 23 & $4 \rightarrow 5$ \\
\hline MJ5 & & & & 331 & 35 & $4 \rightarrow 5$ \\
\hline
\end{tabular}

\begin{tabular}{|c|}
\hline BIEBRZA LOBE [B] \\
\hline $\begin{array}{c}\text { hypothetical direction } \\
\text { of transgression }\end{array}$ \\
\hline $\begin{array}{c}\text { older subglacial } \\
\text { drainage system [B1] }\end{array}$ \\
\hline $\begin{array}{c}\text { younger subglacial } \\
\text { drainage system [B2] }\end{array}$ \\
\hline
\end{tabular}

NEMAN LOBE [N]

hypothetical direction of transgression

older subglacial drainage system [N1]

younger subglacial drainage system [N2]

\begin{tabular}{|c|}
\hline STAGE \\
OF DEGLACIACION \\
\hline the youngest [D5] \\
\hline [D4] \\
\hline the eldest [D1] \\
\hline
\end{tabular}

analysis involved clustering of morpholineaments (vectors) in the intervals of 5 and $10^{\circ}$ up to $180^{\circ}$ every $1 \mathrm{~km}$ along their length, within the examined groups. Cumulative plots present the distribution of morpholineaments according to their direction and geomorphic feature (Fig. 5C.1-C.3). In the next step, the landform vectors were combined on a genetic basis into subglacial and marginal systems, and the resultant (average) direction of each system in every sector was computed.

Based on the mutual relations between the groups of individual post-glacial forms and their orientation, a qualitative analysis was conducted and sectors of potential, active ice sheet lobes were distinguished. These regional zones may be referred to as domains (Fig. 6) within the ice sheet that developed during the particular phases of the glaciation of the area (cf. Evans, 2003).

The obtained directional data, geometric constructions on the DEM, and the palaeogeomorphological analysis, including analysis of the potential depositional effectiveness of the ice sheet (Kozarski and Kasprzak, 1987; Kasprzak, 2003), were used for the reconstruction of subsequent deglaciation stages (Fig. 6), and the dynamics of the Saale ice sheets in the study area (Fig. 5).

\section{RESULTS}

The MMA has allowed for distinguishing 15 sectors of intra-lobe zones (L1-L15) and five sectors referred to as moraine junction zones (MJ1-MJ5; Fig. 5A). Landforms reflecting the advance and retreat of the Saale ice sheet (MIS 6) in the areas of the Sokółka Hills, the Białystok Plateau and the Grodno Plateau were identified in each of these zones.

The advance of the Saale (MIS 6) ice sheet resulted in the formation of terminal basins and subglacial channels.

The obtained results allowed distinguishing two orientations of terminal basins in the morainic plateaux $\left(1-4^{\circ}\right.$ and $\left.5-14^{\circ}\right)$. The resultant directions of the first group of results cluster in the central and western part of the area, that is in sectors from L1 to L4, L8-L9 and L12 (Fig. 5B, C.1 and Table 1). The results of the second group occur in the eastern sectors (L5-L7), L10 and L14 (Table 1). In sector L10, the resultant direction is $14^{\circ}$, and in L11 $-353^{\circ}$ (Fig. 5A and Table 1). Both sectors represent the most extreme fields of the study area. The first is located in its easternmost part and lies directly adjacent to the Neman River Valley. In turn, L11 covers an area in the western part of the study area. 


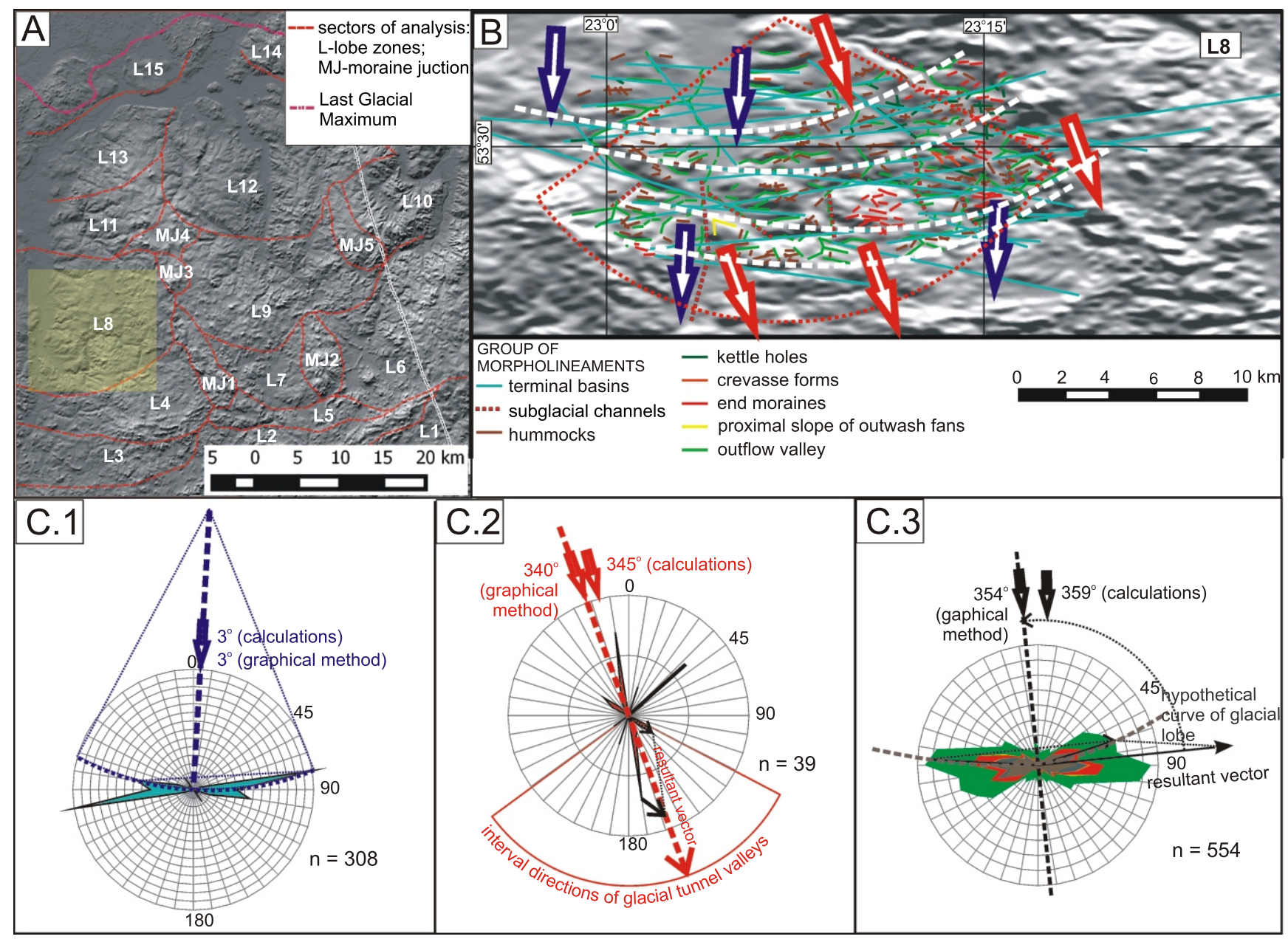

Fig. 5. The main assumptions of the analysis

A - division of the study area into sectors in relation to general geomorphic features and inferred ice sheet limits; $\mathbf{B}$ - typical post-glacial morpholineaments pattern in one of the sector (L8, conformal LonLat projection); C.1 - resultant ice-flow direction based on discrete depressions; C.2 - ice-advance direction based on the subglacial channels; C.3 - hypothetical ice-flow direction during ice sheet margin stagnation (steady-state conditions), reconstruction of palaeo-ice sheet lobe outline (limits). All calculations of resultant directions (vectors) were computed based on vector algebra (addition). For each calculation, all the morpholineaments from all genetic groups considered in particular sector where added to each other one by one and the resultant vector parameters (strike and length) were obtained. Depending on the morpholineaments group(s) the strikes of the resultant vector were rotated by $90^{\circ}$ to refer to the resultant ice-flow direction. Every calculation covers the $180^{\circ}$ interval of morpholineaments strike according to distribution of the data analysed. Strikes of the morpholineaments were computed in GIS environment after vector transformation to conformal latitude-longitude projections. Length of each morpholineament was determined as a weighted unit by every $1 \mathrm{~km}$ of its length measured in equal-area projection of PUWG $92 \mathrm{co}-$ ordinate system. $\mathrm{n}$ - total weighted nominal length of morpholineaments. All graphical constructions were presented on rose diagrams. In graphical construction, only the local maxima (peaks of frequency) in morpholineaments distribution were considered. Morpholineaments clustered within $9^{\circ}$ intervals

Subglacial channels found in the western part of the study area have an orientation in a wide range from 282 to $345^{\circ}$. They comprise two sets: the first with an orientation between 282 and $294^{\circ}$ (L3, L6, L9, L11), and the second with an orientation between 317 and $345^{\circ}$ (L4, L8, L12, L13) (Fig. 5A, C.2 and Table 1). Forms with an orientation of $4^{\circ}(\mathrm{L} 10), 5^{\circ}$ (L14) and $40^{\circ}$ (L07) have also been observed. In turn, in the eastern part of the area, subglacial channels were registered only in two sectors, L6 and L12. Their orientations lie in a relatively narrow range between 36 and $45^{\circ}$ (Fig. 5A, C.2 and Table 1).

Forms recording the interval/intervals of a longer stop of the ice sheet front, represented by end moraines, e.g. near Knyszewicze, Janów and Gliniszcze Wielkie (Fig. 2), edges of outwash fans and eskers have also been identified. For example, in sector L8, the orientation of end moraines is in the range between 47 and $120^{\circ}$, which corresponds to the orientation of the edges of outwash fans and side valleys (Fig. 5B). A subdivision into two zones is also visible as regards the orientation of forms of marginal zones. In the western part of the study area the probable resultant direction of ice-mass flow is in the range of 338 to $360^{\circ}$. A detailed analysis of the collected data indicates a bipartition of the ice sheet flow directions. The first direction is between 344 and $352^{\circ}$ (L1-L7, L9 and L11). A similar direction of ice sheet advance was registered in sectors L14 and L15 located in the northernmost part of the study area, in direct vicinity of LGM moraines (Fig. 5C.3). The second direction is 


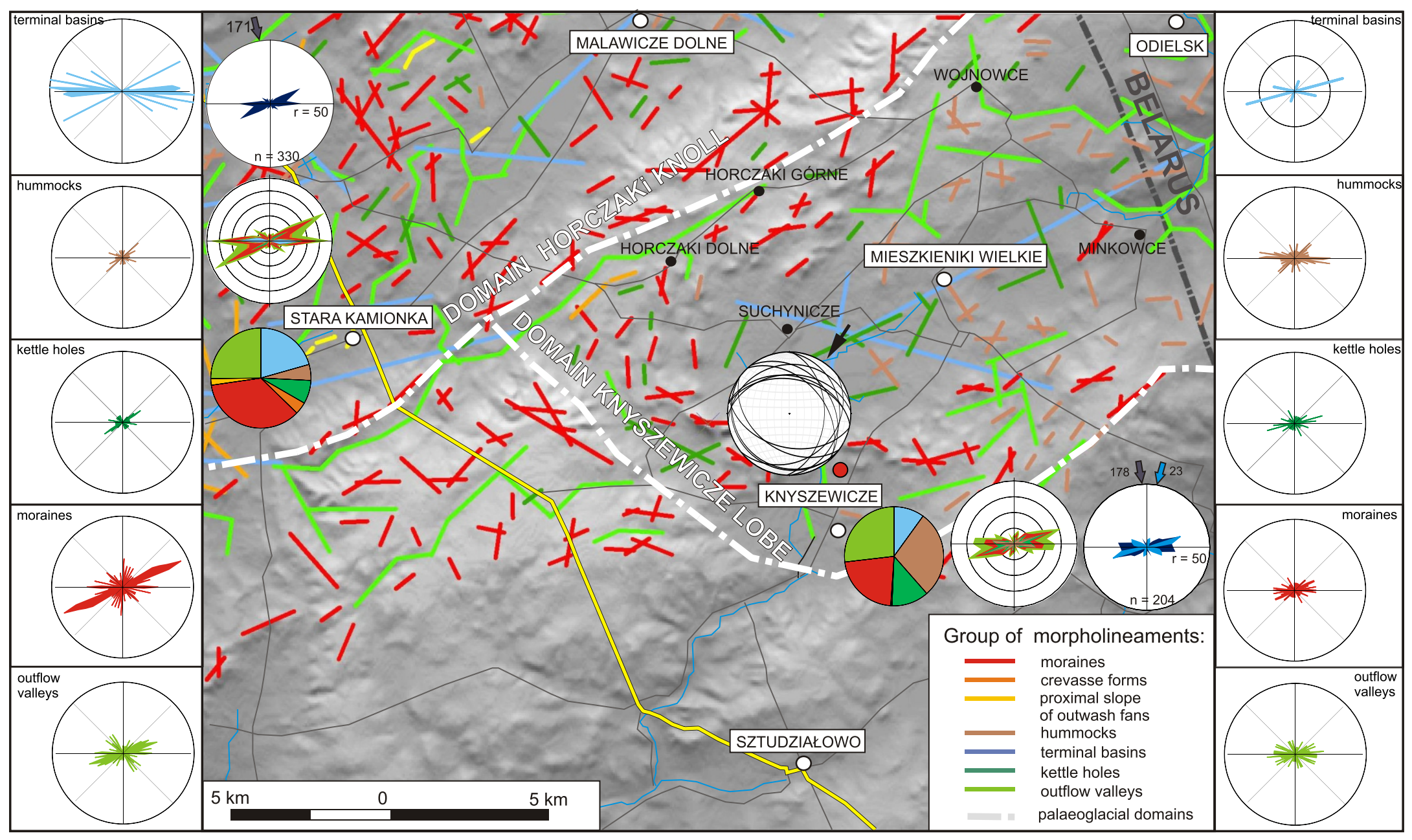

Fig. 6. Results of distribution of glacial morpholineaments in the Knyszewicze marginal zone, and measurement directions faults of glaciotectonic deformation in Knyszewicze outcrop (after Rychel et al., 2015, completed) 
between 355 and $3^{\circ}$ (L8, L10, L12, L13). In turn, in the eastern part of the study area, the direction of ice sheet advance is between 23 and $40^{\circ}$ (Table 1).

In sectors MJ1-MJ5, which represent the moraine junction, the resultant direction of ice-mass flow was from the NNW $\left(325-355^{\circ}\right)$ and NE $\left(8-45^{\circ}\right)($ Table 1$)$. Height differences between particular hills in these areas are from 10 even to $30 \mathrm{~m}$. Their orientation in sectors MJ1, MJ3 and MJ4 is NNW-SSE, and in sector MJ2 - N-S (Fig. 5A).

An interesting example of the marginal part of the Saale ice sheet is the area analysed in sectors L1 and L2. They cover the area of the villages of Knyszewicze (L1) and Horczaki Knoll (L2) (Fig. 7). Detailed analysis of the post-glacial morpholineaments carried out at the Knyszewicze site resulted in the identification of two glacial segments, i.e. Horczaki Knoll and Knyszewicze,
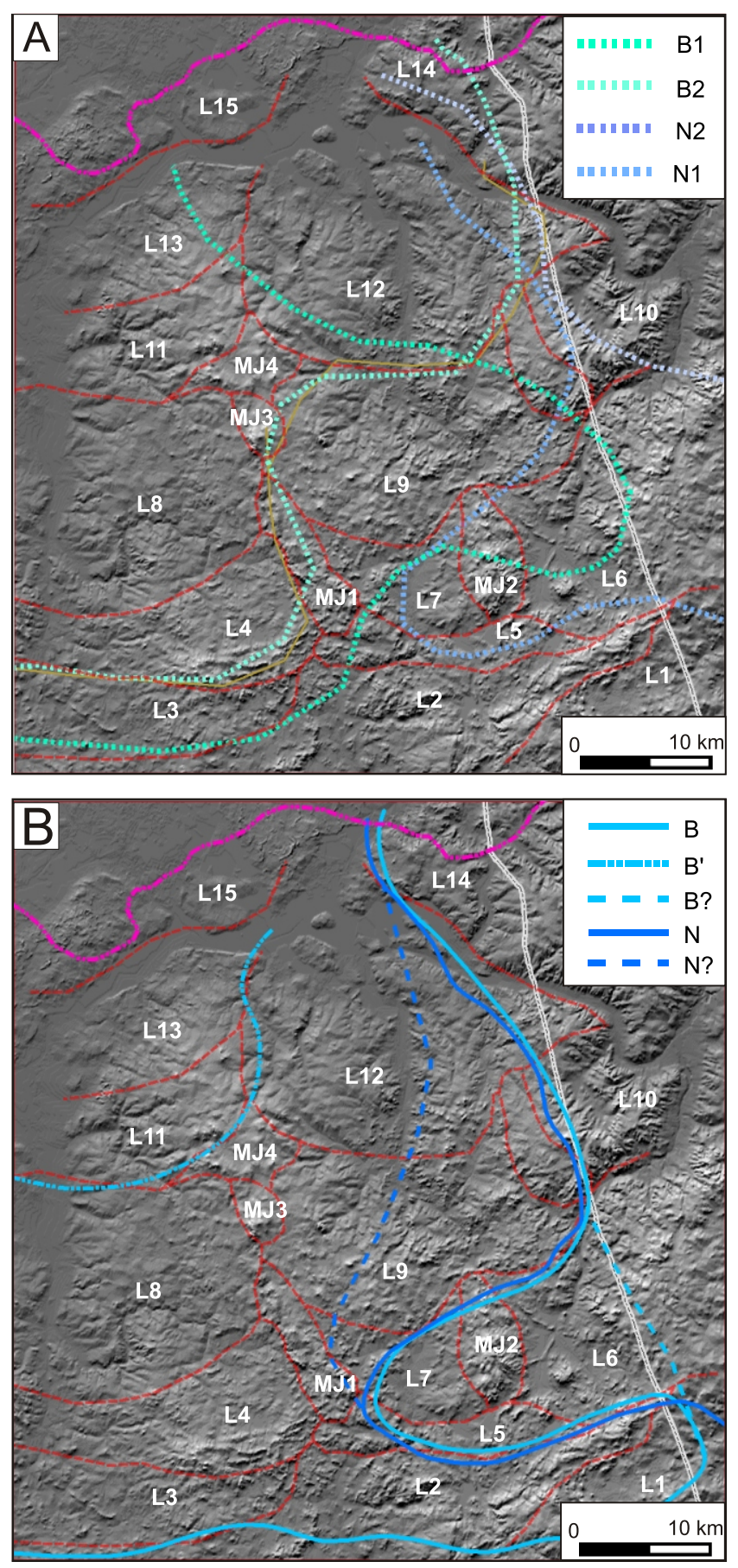

which is confirmed by different directions of the ice sheet movement, i.e. 171 and $23^{\circ}$, respectively (Fig. 6). The dip of faults found at the Knyszewicze site is in the range of $11-44^{\circ}$, which corresponds to a NNE direction of the advance (Szymczuk, 2014; Rychel et al., 2015), being a field evidence confirming the palaeoglaciological interpretation derived from the analysis of morpholineaments arrangement. The resultant azimuth of the dominant ice sheet advance $\left(171^{\circ}\right)$ is widespread over the entire study area and likely corresponds to the main transgression direction from the NNW. The second azimuth $\left(23^{\circ}\right)$ corresponds to the thrust-fault measurements made on the eastern wall of the Knyszewicze outcrop (Rychel et al., 2015). This is indicated by the ice sheet movement from the NNE in the Knyszewicze region (Fig. 6).

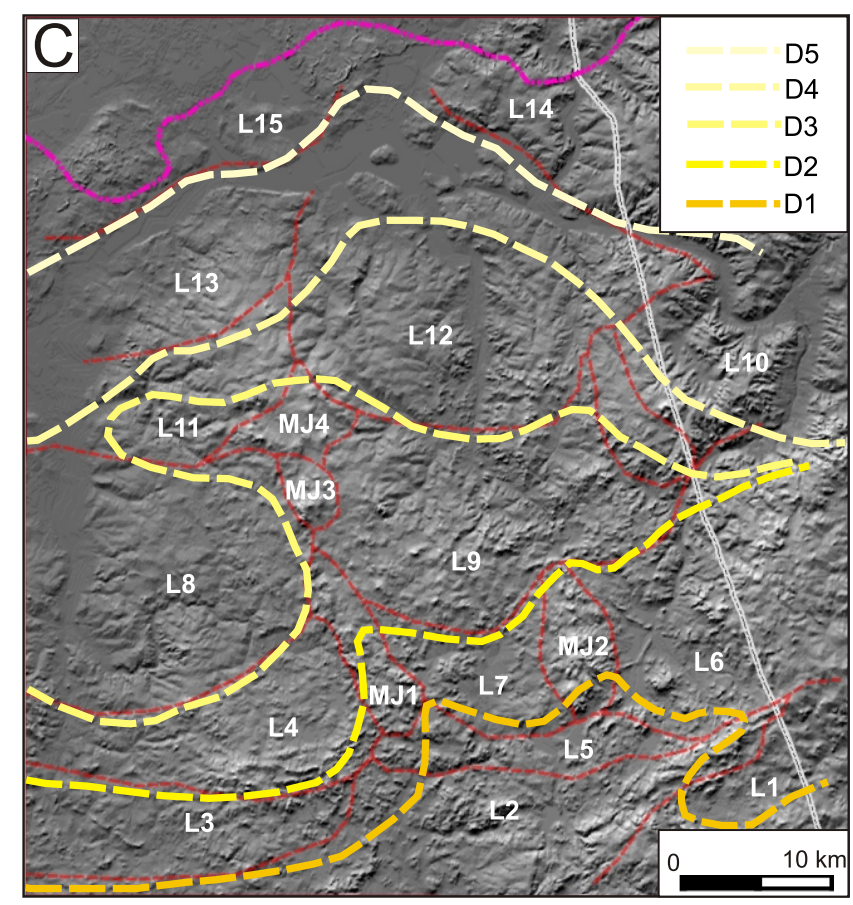

\section{Fig. 7. Results of sequential analysis of morpholineaments}

A - active drainage systems, $\mathbf{B}$ - sectors of potential active ice sheet lobes (B - Biebrza lobe, N - Neman lobe), C - D1-D5 stages of the area deglaciation, vide Table 1 


\section{DISCUSSION}

Characteristic elements of the morphology of the marginal part of Pleistocene ice sheets on land were glacial lobes, which represented their most dynamic part (Booth et al., 2003; Mickelson and Colagan, 2004; Winguth et al., 2004; Turkowska, 2006; Przybylski, 2008; Wysota and Molewski, 2011; Dzieduszyńska et al., 2014). Mechanisms of development and evolution of ice sheet lobes in the European Lowland and North America during the Pleistocene have been broadly discussed by many researchers over the last decades (Evans and Rea, 2005; Boulton and Hagdorn, 2006; Jennings, 2006; Narloch et al., 2013). The morphological axis of the developing lobes are, e.g., depressions/old valleys existing in the landscape, on which the ice sheet advanced (Mickelson and Colagan, 2004; Wysota and Molewski, 2011; Dzieduszyńska et al., 2014; Hermanowski, 2015).

\section{PALAEOGEOGRAPHIC RECONSTRUCTION OF THE SAALE GLACIATION IN THE SOKÓŁKA HILLS}

Assumptions of the palaeoglaciological inversion model (Kleman and Borgstrom, 1996; Clark, 1997; cf. Benn and Evans, 2010) were used in the reconstruction of the varying Saale ice sheet dynamics and in setting the relative chronology of glacial events during deglaciation of the Sokółka Hills area (Figs. 7 and 8). The inversion model, i.e. reconstruction of the chronological sequence of events, is prepared based on the identification of forms starting from the youngest (best preserved) ones and continuing through the older forms whose level of preservation becomes worse.

The differences in the orientation of terminal basins within the morainic plateaux in the Sokółka Hills, the eastern part of the Białystok Glacial Plateau, and the western part of the Grodno Plateau are indicative of the bipartition of ice sheet flow directions in the study area, which may serve as indirect evidence for the activity of two ice sheet lobes that covered its eastern (Neman lobe) and western (Biebrza lobe) parts (Ber et al., 2012). Likewise, Karabanov (1987) described variable directions of the Saale ice sheet advance in this region. His observations were based mainly on the analysis of glaciotectonic structures. The central part of the Sokółka Hills is an area where the zones of impact of the two lobes overlap, creating ice-lobe convergence forms (Fig. 8) - "interlobate moraines" (e.g., Punkari, 1980; Brennand et al., 1996). "Interlobate moraines" were formed in this zone (e.g., Punkari, 1980; Brennand et al., 1996). According to the DGMP, the moraine junction zones in the Sokółka Hills are composed of gravels, boulders and glacial tills of end moraines, which build the highest elevations in the area (Boratyn, 2006; Wrotek, 2009). The lithology of forms of such origin was also described by Brennand et al. (1996) in northern Quebec, Canada. Forms correlated with the ice-lobe convergence zone of the Saale ice sheet were also distinguished in the Łódź Plateau (Turkowska, 2006; Dzieduszyńska et al., 2014).

Clustering of resultant vectors within the study area may also be noticed in the orientation of the morpholineaments identified as former subglacial chanels (Fig. 7A). A typical orientation for the western part of the study area (in the Biebrza lobe) is ca. 290 and $330^{\circ}$, whereas the eastern part (Niemen lobe) is represented by resultant vectors with a more northeastern strike $-\sim 40$ and $5^{\circ}$ (cf. Table 1 ). The above supports the hypothesis of two individual ice sheet lobes in the analysed area. Morpholineaments related to the subglacial drainage group prove multiple changes in the dynamics of the entire ice sheet and reveal the mutual relationships between the inferred ice sheet lobes. Trends in the changing orientation of the forms related to the subglacial drainage enabled us to reconstruct the range of the ice sheet lobes (Fig. 7B). Changes observed in the subglacial drainage system could be indicated the pulsating nature of the ice movement, and indicate episodes of intense subglacial drainage, which was particularly well-developed in the western sector. Episodes of intense ice flow, which ended in the creation of a system of subglacial channels, were probably preceded by periods of crawling of ice masses.

A complex orientation of the glacial forms of the marginal zone system within the individual sectors enabled us to draw conclusions on the chronology of the glaciation events. The prevailing direction from the NNW $\left(290^{\circ}\right.$ - sector L4) seems to reflect more climatic rather than glacio-dynamic factors. The progressive improvement of the climatic conditions imposed a constant longitudinal sequence of deglaciation of the subsequent sectors across the study area. The sequence was only slightly modified by the active ice movement or by the re-advance of the individual parts of the ice sheet. The possible traces of the glacio-dynamic impact from the NE, $\sim 40^{\circ}$ (corresponding to the Neman lobe), are marked in the system of marginal morpholineaments as a second-level, coupled, lower frequency morpholineament system. The analysis of the resultant directions of the marginal morpholineament systems in the individual sectors and their relationships within the morainic junctions was used to reconstruct a likely scheme of deglaciation isochrones (Fig. 7C).

The Biebrza lobe has a fully developed system of post-glacial morpholineaments. Each of the systems is clearly represented and the number of morpholineaments is sufficient to perform a statistical analysis. In the case of the Neman lobe, the number of morpholineaments related to the subglacial system is low and therefore the results for these groups of morpholineaments should be considered only as indicative.

\section{STAGES OF THE SAALE ICE SHEET ADVANCE IN THE SOKÓŁKA HILLS}

Based on MMA, the reconstruction of MMA advances and retreats of the Saale ice sheet in the Sokółka Hills was performed:

\section{Stage I - advance of the Saale ice sheet}

The resultant directions of ice advance, derived from morpholineaments, have revealed that both the Biebrza and Neman ice lobes had a similar flow direction which suggests that they might have used one regional corridor for the ice sheet flow. The variable activity of the individual ice sheet sectors is assumed to be a result of local changes in the ice-mass balance and location of the local ice divide.

The early phases of ice sheet activity recognized in the Sokółka Hills are associated with the mutual confluent flow within both sectors of the ice sheet (Fig. 8A). The setting up of the terminal basins within the future glacial moraine plains should be related to this period. The range of the ice sheet at this stage of the Saale Glaciation in eastern Poland and western Belarus probably reached much further to the south of the study area. 


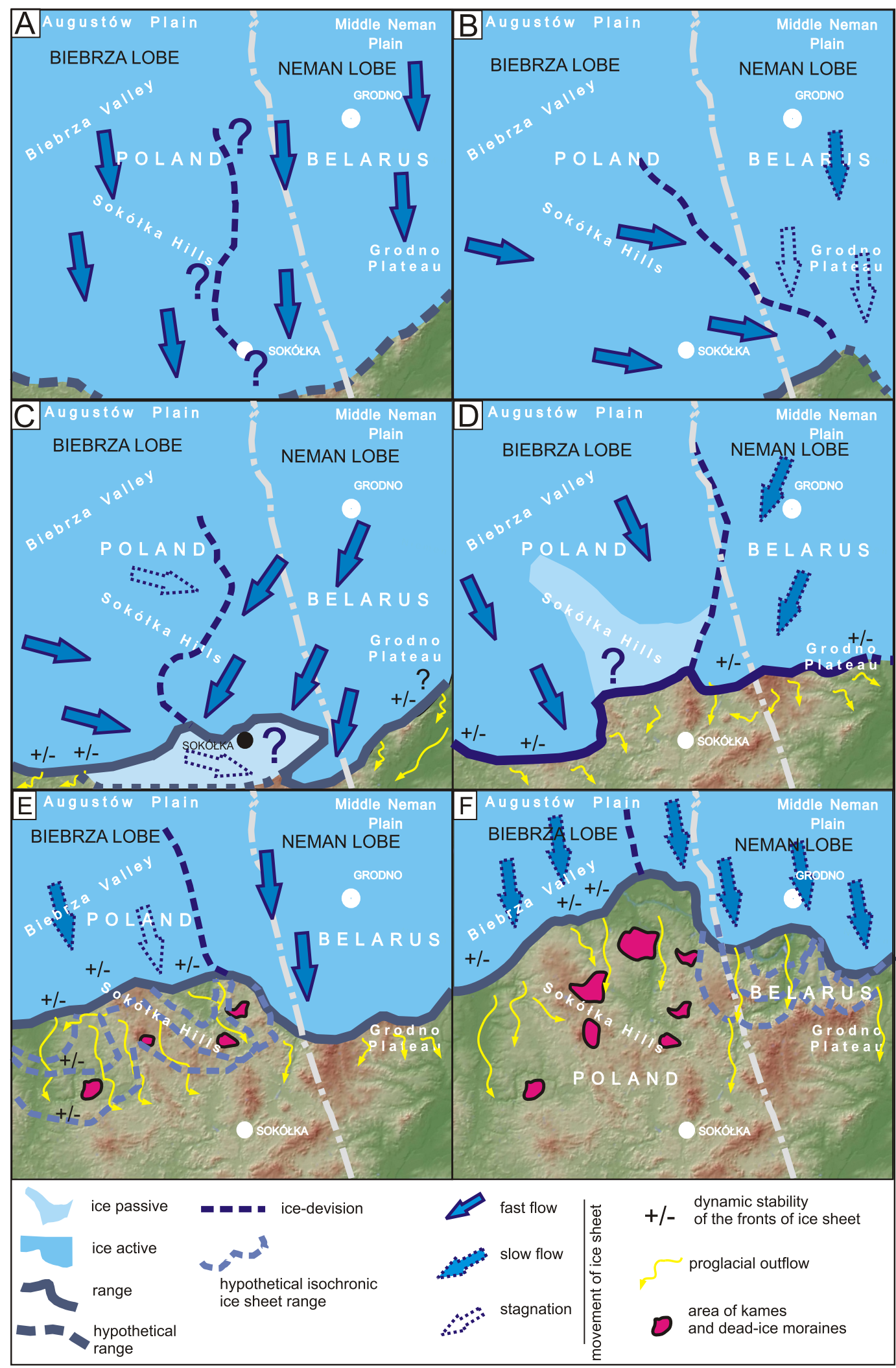

Fig. 8. Palaeogeographic reconstruction of the last glaciation in the Białystok Plateau and Sokółka Hills

A - glaciation; B - flow of ice masses in the Biebrza lobe; C - flow of ice masses in the Neman lobe; D - reorganization of ice-mass flow in the Biebrza lobe; E, $\mathbf{F}$ - deglaciation, confluent ice sheet lobes 


\section{Stage II - activation of the Biebrza lobe}

The next event that could be identified was a concentrated flow towards the WNW within the Biebrza lobe, combined with the development of a channelled subglacial drainage system $\left(\sim 290^{\circ}\right.$ - the older drainage system; cf. Table 1). This stage was probably contemporaneous with the stagnation within the Neman lobe - the eastern sector of the ice sheet (Fig. 8B).

\section{Stage III - activation of the Neman lobe}

The reactivation of the Neman lobe occurred in the following stage, which was related to the evolution of the NE-SW $\left(\sim 40^{\circ}\right)$ subglacial drainage system identified in the southeastern part of the study area (Table 1). This event may be related to the formation of glaciotectonic deformations described in a small lobe at Knyszewicze, which was a protrusion of the Neman ice lobe, roughly $12 \mathrm{~km}$ long and $4 \mathrm{~km}$ wide (Rychel et al., 2015). During this episode, partial reorganization and overlapping of the terminal basins systems might have occurred within the morainic plateaux in sectors L6 and L7. Simultaneously, the development of proglacial outflows, related with a distinct marginal zone in the western part of the area, indicates continuous flow of the ice masses from the interior of the eastern sector of the ice sheet (Fig. 8C).

\section{Stage IV - reorganization of the Biebrza lobe}

Another rearrangement of the coupled lobe system took place during the deglaciation and the accompanying alimentation system changes. The ice of the Neman lobe entered a stabilization phase, whereas the inflow of the ice masses into the Biebrza lobe concentrated in the axes of two terminal basins in the western and central part of the area (Fig. 8D).

\section{Stages $\mathrm{V}$ and $\mathrm{VI}$ - deglaciation}

The subsequent stages comprised successive deglaciation of the western area (with a noticeable trend towards the formation of ice sheet lobes extending along the main terminal basins axes) and the increased ice sheet dynamics in the eastern sector (Fig. 8E, F). The pattern and the orientation of the post-glacial morpholineaments within the two ice sheet lobes indicate slightly different glacio-dynamic conditions.

In the case of the Biebrza lobe, the changing orientation may be observed both in the post-glacial channels and in the morpholineaments of the marginal and intra-lobe system. It may be related to the pulsating nature of the ice inflow. Each episode of the concentrated flow (streaming) of the ice sheet ends with the development of a channelled subglacial drainage system and a stagnation period. The relief, extension and geomorphological expression of the marginal zones in the west are indicative of the prolonged periods of dynamic equilibrium of the ice sheet front, which could be achieved by continuous alimentation of the ice margin by fresh ice (cf. Kozarski and Kasprzak, 1987). Considering the above statements, one should assume the existence of minor differences in the movement rate of the ice body during the concentrated (ice-streaming) and normal ice flow. A concentrated flow of the ice sheet is possible during periods of significant improvement in the climate conditions, when the climate warming causes an increased supraglacial meltwater production which, in turn, remains in relation to the rheological conditions in the ice sheet sole, causing more favourable conditions for basal sliding and other meltwater related forms of enhanced ice flow.

The morpholineaments pattern of the Neman lobe implies that the main area of its impact was located further to the east, and only part of its marginal limit may be observed in the study area. Low frequency of the subglacial morpholineaments leads to the hypothesis of different (more abrupt in its nature) ice flow mechanisms, i.e. surges. Both the expression of the marginal zones in the eastern part of the study area, and the periods of increased activity of the eastern ice sheet lobe (interpreted on the basis of the orientation of glacial morpholineaments more variable in the resultant direction, cf. Table 1) may be associated with the crossing of subsequent rheological barriers by the ice sheet. In this instance, areas of faster ice flow, marked by a distinct subglacial morpholineaments pattern, may be observed on the distal zones of basement elevations.

\section{INFLUENCE OF BASEMENT MORPHOLOGY ON THE ICE SHEET MOVEMENT}

The limits and dynamics of both the Biebrza and Neman ice sheet lobes and the smaller lobes in the marginal zones of the ice sheets (like those at Knyszewicze) are largely pre-determined by the basement topography and its geological structure (rheological parameters of particular basement layers and its configuration). The Geological map of the northern borderland between Poland and Belarus at the scale of 1:250,000 (Marks and Karabanov, 2011) contains a supplementary geological map of the pre-Quaternary deposits. A model of the Quaternary deposits was generated with the use of interpolated isolines of the Quaternary floor elevation (Fig. 9).

Distinct elevation differences within the Neogene, Paleogene and the Cretaceous basement had a significant impact on the direction and rate of the ice sheet advance. Axes of both lobes, i.e. the Biebrza lobe and the Neman lobe, correspond to the outline of the main terminal basins in this area. Nowadays, the same alignment is recognizable in the network pattern of major rivers, after which the lobes were named. The intra-lobe zones, where the ice mass was assumed to be of greater thickness (allowing faster ice flow rates), were located in large depressions, for instance in the vicinity of Sztabin or Lipsk (northern sector of the study area). The moraine junction zones, recognized, e.g., near Gliniszcze Wielkie and Janów (Fig. 1), reflect elevations or escarpments of the pre-Quaternary basement. The ice sheet advance might have triggered tectonic movements within the basement, which is confirmed by the presence of glaciotectonically disturbed zones, e.g. to the west and north-west of Grodno, where Cretaceous rocks were uplifted and are at present extracted in open pit mines. Such an arrangement is observed mainly in the eastern sector, where the Neman lobe was delimited. Assuming the overlapping of the glacial sedimentological succession and repetition of morphogenesis over particular glacial periods for certain regions of northeastern Poland (Morawski, 2009b), the dynamics of the ice masses and spatial limits of the Neman lobe were constrained by former structural elements which prevented the development of broad marginal zones in the area and fast-ice-flow features. The influence of tectonic structures on the origin of lobes during the Main Stadial of the Vistulian Glaciation in northeastern Poland was also described by Morawski (2005), and for the Saale ice sheet in central Poland - by e.g. Turkowska (2006) and Dzieduszyńska et al. (2014).

\section{CONCLUSIONS}

Analysis of the post-glacial morpholineaments in the areas of the Białystok Glacial Plateau and Sokółka Hills (NE Poland) has confirmed that the present-day landscape of this region was created during one glaciation by the activity of the Wartanian Stadial of the Odranian Glaciation.

The second-level differences in the pattern of morpholineaments have allowed distinguishing individualized domains 


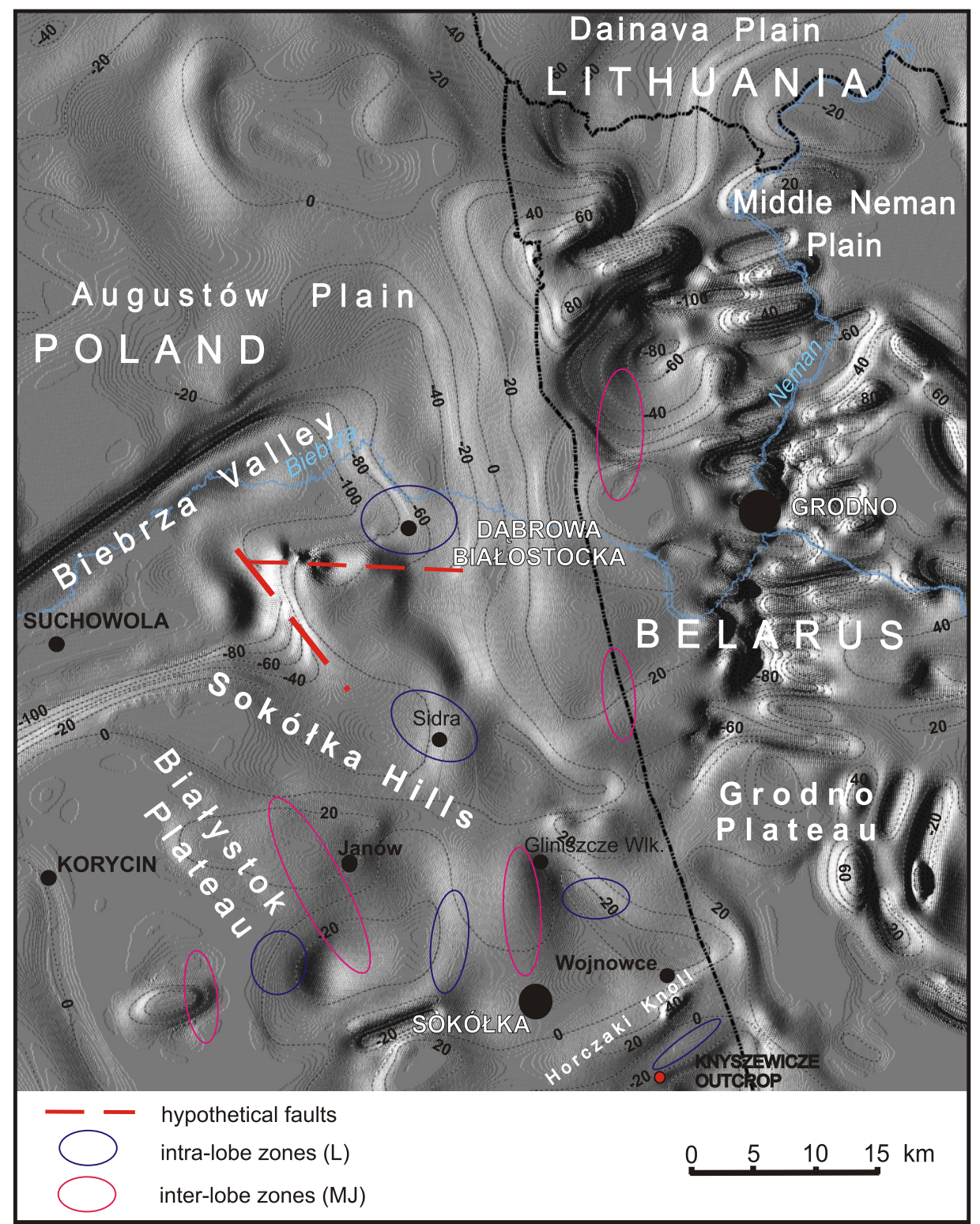

Fig. 9. Relief of the pre-Quaternary basement

related to varying temporal dynamics of two ice sheet elements: ice-mass flow of the Biebrza and Neman lobes in the north-east.

The most probable model for the inferred dynamics of the ice sheet lobes may be explained by a cyclical reverse feedback where the greater activity of one lobe resulted in the stagnation of the second lobe fed from the same alimentation area.

The pulsating ice sheet movement during the Wartanian Stadial in the Sokółka Hills is confirmed by the general geomorphological character of the area, where glaciotectonically disturbed landforms (created during periods of intensive ice inflow) are accompanied by the zones of hummocky moraines or kames, that is landforms created in various sedimentary environments in areal deglaciation conditions (ice sheet stagnation). Correlation of the results of the structural measurements made at Knyszewicze with the analysis of the morpholineaments arrangement in the area positively verifies the remote method as indicative for the reconstruction of the palaeo-ice-sheet movement.
The ice sheet of the Wartanian Stadial of the Odranian Glaciation (Saale - MIS 6) advanced on the area that had been covered by sediments of various origins and with pre-Odranian relief. Both the thickness and the structure of the basement affected the ice movement dynamics (Dzierżek, 2009; Czubla, 2015). It is confirmed in the Horczaki Knoll that might have functioned as an elevation and a barrier for the ice body during the last ice sheet advance in the Knyszewicze area. This elevation functions above Neogene and Paleogene deposits, which are tectonically displaced.

The contemporary relief corresponds to the main features and structures detected in the basement of the Quaternary series. The basement relief was a very important factor differentiating the dynamics of particular ice lobes.

Application of the Geographic Information Systems (GIS) allows a detailed chronological reconstruction of the sequence of events according to the palaeoglaciological inversion models. They enable collecting, processing and integrating large 
amounts of data from numerous sources. Thus, the analysis of post-glacial morpholineaments applied in this study may represent a universal tool for integrated, (trans)regional palaeogeomorphological and palaeogeographical analysis, providing a new approach and opportunity to check varying hypothetical models of ice sheet development.
Acknowledgements. We wish to thank B. Gruszka and $V$. Zelčs for valuable suggestions that improved the quality of this paper. The research was funded by the grant of the Polish Ministry of Science and Higher Education (decision No. 497/NBIAŁORUŚ/2009/0) and research project No. UMO2013/09/B/ST10/02118.

\section{REFERENCES}

Banaszuk, H., 2010. O wieku i genezie rzeźby polodowcowej Niziny Północnopodlaskiej na podstawie analizy geomorfologicznej dat TL (in Polish). In: Zagadnienia morfogenezy Niziny Północnopodlaskiej. (eds. H. Banaszuk and P. Banaszuk). Oficyna Wydawnicza Politechniki Białostockiej, Białystok.

Benn, D.I., Evans, D.J.A., 2010. Glaciers and Glaciation. Hodder Arnold Publications, London.

Ber, A., Krzywicki, T., Marks, L., Nowacki, Ł., Pochocka-Szwarc, K., Rychel, J., Woronko, B., 2012. Rozwój rzeźby wzgórz Sokólskich i Wysoczyzny Grodzieńskiej w czasie zlodowacenia Odry (in Polish). In: Czynniki różnicowania rzeźby Niżu Polskiego (eds. D. Dzieduszyńska and M. Roman): 71-73. Uniejów 13-15 czerwca 2012, Uniwersytet Łódzki.

Bindschadler, R.A., Vornberger, P., 1998. Changes in the West Antarctic Ice-sheet since 1963 from declassified satellite photography. Science, 279: 689-692.

Bitinas, A., 2012. New insights into the last deglaciation of the south-eastern flank of the Scandinavian Ice-sheet. Quaternary Science Reviews, 44: 69-80.

Booth, D.B., Troost, K.G., Clague, J.J., Waitt, R.B., 2003. The cordilleran ice sheet. Developments in Quaternary Sciences, 1: $17-43$.

Boratyn, J., 2006. Objaśnienia do szczegółowej mapy geologicznej Polski w skali 1:50 000, ark. Sokółka i Sokółka E (in Polish). Państwowy Instytut Geologiczny, Warszawa.

Boulton, G.S., Clark, C.D., 1990. A highly mobil Laurentide ice-sheet revealed by satellite images of glacial lineations. Nature, 364: 813-817.

Boulton, G.S., Hagdorn, M., 2006. Glaciology of the British Isles Ice Sheet during the last glacial cycle: form, flow, streams and lobes. Quaternary Science Reviews, 25: 3359-3390.

Boulton, G.S., Dongelmans, P., Punkari, M., Broadgate, M., 2001. Palaeoglaciology of an ice sheet through a glacial cycle: the European ice sheet through the Weichselian Quaternary Science Reviews, 20: 591-625.

Brennand, T.A., Shaw, J., Sharpe, D.R., 1996. Regional-scale meltwater erosion and deposition patterns, northern Quebec, Canada. Annals of Glaciology, 22: 85-92.

Brykczyński, M., 1986. On the main directions of the development of the Polish lowland river network in the Quaternary (in Polish with English summary). Przeglad Geograficzny, 57: 411-440.

Clark, C.D., 1993. Mega-scale glacial lineations and cross-cutting ice-flow landforms. Earth Surface Processes and Landforms, 18: 1-29.

Clark, C.D., 1994. Large-scale ice-moulding: a discussion of genesis and glaciofluvial significance. Sedimentary Geology, 91: 253-268.

Clark, C.D., 1997. Reconstructing the evolutionary dynamics of former ice sheets using multi-temporal evidence, remote sensing and GIS. Quaternary Science Reviews, 16: 1067-1092.

Clark, C.D., 1999. Glaciodynamic context of subglacial bedform generation and preservation. Annals of Glaciology, 28: 23-32.

Czubla, P., 2015. Fennoscandian erratics in glacial sediments of Poland and their research significance (in Polish with English summary). Wydawnictwo Uniwersytetu Łódźkego, Łódź.
Dzieduszyńska, D., Petera-Zganiacz, J., Roman, M., Machecka-Kotkowska, L., 2014. Glacial-interglacial cycles in Central Poland as reflected in the Łódź University geomorphological scientific achievements. In: Origin of Relief of Central Poland and its Anthropogenic Transformation in Łódź University Geographical Research (ed. E. Kobojek and T. Marszał): 29-56. University of Łódź.

Dzierżek, J., 2009. Paleogeography of selected areas of Poland during the last glaciation (in Polish with English summary). Acta Geographica Lodziensia, 95: 1-112.

Dylik, J., 1953. Du caractère périglaciaire de la Pologne Centrale (in Polish with French summary). Acta Geographica Universitatis Lodziensis, 4: 1-109.

Evans, D.J.A., Rea, B.R., 2005. Surging glacier land system. In: Glacial Systems (ed. D.J.A. Evans): 259-288. Arnold.

Evans, D., Young, N., Cofaigh, C., 2014. Glacial geomorphology of terrestrial-terminating fast flow lobes/ice streams margins in the southwest Laurentide ice sheet. Geomorphology, 204: 96-113.

Ewertowski, M., Rzeszewski, M., 2006. Using DEM to recognize possible minor stays of Vistulian (Weichselian) ice-sheet margin in the Wielkopolska Lowland. Quaestiones Geographicae, 25A: $7-21$.

Fahnestock, M., Bindschadler, R., Kwok, R., Jezek, K., 1993. Greenland ice-sheet surface properties and dynamics from ERS-1SAR imagery. Science, 262: 1530-1538.

Galon, R. ed., 1972. Geomorfologia Polski (in Polish). PWN Warszawa.

Gabrielsen, R.H., Braathen, A., Dehls, J., Roberts, D., 2002. Tectonic lineaments of Norway. Norsk Geologisk Tidsskrift, 82: 153-174.

Gilewska, S., 1991. Rzeźba (in Polish). In: Geografia Polski. Środowisko przyrodnicze (ed. L. Starkel): 248-296. PWN, Warszawa.

Graniczny, M., 1989. Fotolineamenty i ich znaczenie geologiczne (in Polish). Instrukcje i Metody Badań Geologicznych, 50: 1-72.

Graniczny, M., Doktór, S., Kucharski, R., 1995. Sprawozdanie z opracowania mapy liniowych elementów strukturalnych Polski w skali 1: 200000 i 1:500 000, na podstawie kompleksowej analizy komputerowej zdjęć grawimetrycznych i teledetekcyjnych (in Polish). NAG PIG-PIB, nr arch.117/96.

Greenwood, S., Clark, C., 2009a. Reconstructing the last Irish Ice sheet 1: changing flow geometries and ice flow dynamics deciphered from the glacial landform record. Quaternary Science Reviews, 28: 3085-3100.

Greenwood, S., Clark, C., 2009b. Reconstructing the last Irish Ice-sheet 2: a geomorphologically-driven model of ice-sheet growth, retreat and dynamics. Quaternary Science Reviews, 28: 3101-3123.

Hermanowski, P., 2015. Substratum morphology and significance during the Weichselian Odra ice lobe advance in northeast Germany and northwest Poland. Geologos, 21: 241-248.

Jania, J., 1997. The problem of Holocene glacier and snow patches fluctuations in the Tatra Mountains: a short report. Paleoclimate Research, 24: 85-93.

Jennings, C., 2006. Terrestrial ice streams. Geomorphology, 75 100-124. 
Kacprzak, L., Lisicki, S., 2007. Szczegółowa Mapa Geologiczna Polski w skali 1:50 000, ark. Sztabin (in Polish). Państwowy Instytut Geologiczny, Warszawa.

Kalm, V., 2012. Ice-flow pattern and extent of the last Scandinavian Ice-sheet southeast of Baltic Sea. Quaternary Science Reviews, 44: 51-59.

Karabanov, A.K., 1987. Grodnenskaya vozvyshennost: stroyeniye, relyef, etapy formirovaniya (in Russian). Nauka i Tekhnika, 1062.

Kasse, C., 1997. Cold-climate aeolian sand-sheet formation in North-Western Europe (c. 14-12.4 ka); a response to permafrost degradation and increased aridity. Permafrost and Periglacial Processes, 8: 295-311.

Kasprzak, L., 2003. Model of the Vistulian ice-sheet sedimentation in the Wielkopolska Lowland (in Polish with English summary). Wydawnictwo Naukowe UAM w Poznaniu, Seria Geografia, 66 : $1-214$.

Kasse, C., Vandenberghe, J., van Huissteden, J., Bohncke, S.J.P., Bos, J.A.A., 2003. Sensitivity of Weichselian fluvial systems to climate change (Nochten mine, eastern Germany). Quaternary Science Reviews, 22: 2141-2156.

Kehew, A., Piotrowski, J.A., Jørgansen, F., 2012. Tunnel valleys: concepts and controversies - a review. Earth-Science Reviews, 113: $33-58$.

King, E.C., Pritchard, H.D., Smith, A.M., 2016. Subglacial landforms beneath Rutford Ice Stream, Antarctica: detailed bed topography from ice-penetrating radar. Earth System Science Data, 8: 151-158.

Kmieciak, M., 2006. Szczegółowa Mapa Geologiczna Polski w skali 1:50 000, ark. Nowowola (in Polish). Państwowy Instytut Geologiczny, Warszawa.

Kleman, J., Borgstrom, I., 1996. Reconstruction of palaeo-ice sheets: the use of geomorphological data. Earth Surface Processes and Landforms, 21: 893-909.

Kondracki, J., 2009. Geografia regionalna Polski (in Polish). PWN, Warszawa.

Kozarski, S., Kasprzak, L., 1987. Facies analysis and depositional models of Vistulian ice-marginal features in northwestern Poland. In: International Geomorphology (ed. V. Gardiner): 693-710. John Wiley and Sons, New York.

Krzywicki, T., 1999. Maksymalny zasięg lądolodu zlodowacenia Wisły w północno-wschodniej Polsce i obszarach przyległych (in Polish). Ph.D. thesis, Państwowy Instytut Geologiczny, Warszawa.

Krzywicki, T., 2001a. Szczegółowa Mapa Geologiczna Polski w skali 1:50 000, ark. Rygol (in Polish). Państwowy Instytut Geologiczny, Warszawa.

Krzywicki, T., 2001b.Szczegółowa Mapa Geologiczna Polski w skali 1:50 000, ark. Rudawka (in Polish). Państwowy Instytut Geologiczny, Warszawa.

Krzywicki, T., 2002. Szczegółowa Mapa Geologiczna Polski w skali 1:50 000, ark. Stacja Augustów (in Polish). Państwowy Instytut Geologiczny, Warszawa.

Krzywicki, T., 2005. Szczegółowa Mapa Geologiczna Polski w skali 1:50 000, ark. Lipsk (in Polish). Państwowy Instytut Geologiczny, Warszawa.

Kozłowski, I., 2006. Szczegółowa Mapa Geologiczna Polski w skali 1:50 000, ark. Suchowola (in Polish). Państwowy Instytut Geologiczny, Warszawa.

Lamsters, K. 2012. Drumlins and related glaciogenic landforms of the Madliena Tilted Plain, Central Latvian Lowland. Bulletin of the Geological Society of Finland, 84: 45-57.

Majdanowski, S., 1950. The problem of lake-channels in the European Plain (in Polish with English summary). Badania Fizjograficzne nad Polską Zachodnia, 2: 35-122.

Majewska, A., 2008a. Szczegółowa Mapa Geologiczna Polski w skali 1:50 000, ark. Nowy Dwór (in Polish). Państwowy Instytut Geologiczny, Warszawa.

Majewska, A., 2008b. Szczegółowa Mapa Geologiczna Polski w skali 1:50 000, ark. Rygałówka (in Polish). Państwowy Instytut Geologiczny, Warszawa.
Marks, L. ed., 2006. Geologiczne Mapa Polski 1:500 000 (in Polish). Państwowy Instytut Geologiczny, Warszawa.

Marks, L., 2012. Timing of the Late Vistulian (Weichselian) glacial phases in Poland. Quaternary Science Reviews, 44: 81-88.

Marks, L., Karabanov, A. eds., 2011. Mapa geologiczna północnej części obszaru przygranicznego Polski i Białorusi 1:250 000 (in Polish). Państwowy Instytut Geologiczny, Warszawa.

Mickelson, D.M., Colagan, P.M., 2004. The southern Laurentide Ice Sheet. In: Quaternary Period in the United States (eds. A.R. Gillespie, S.C. Porter and B.F. Atwater): 1-16. Elsevier.

Mojski, E., 1972. Nizina Podlaska (in Polish). In: Geomorfologia Polski, 2 (ed. R. Galon): 318-362. PWN, Warszawa.

Morawski, W., 2003. Reconstruction of ice-sheet movement from the orientation of linear glacial landforms and glaciotectonic deformations near Kronowo (western Mazury, Poland). Geological Quarterly, 47 (4): 339-356.

Morawski, W., 2005. Reconstruction of ice-sheet movement from the orientation of glacial morpholineaments (crevasse landforms): an example from northeastern Poland. Geological Quarterly, 49 (4): 403-416.

Morawski, W., 2009a. Neotectonics induced by ice-sheet advances in NE Poland. Geologos, 15: 199-217.

Morawski, W., 2009b. Reconstruction of the Vistula ice stream during the Last Glacial Maximum in Poland. Geological Quarterly, 53 (3): 305-316.

Morawski, M., 2015. Sekwencyjna analiza geomorfolineamentów polodowcowych jako narzędnie rekonstrukcji paleogeograficznych (in Polish). In: Krajobrazy młodoglacjalne, ich morfogeneza, teraźniejszość, przyszłosć (eds. P. Molewski and W. Juśkiewicz): 77. Toruń 16-19 września, 2015, Uniwersytet Mikołaja Kopernika.

Musiał, A., 1992. The glacial landscape of Northern Podlasie (in Polish with English summary). Rozprawy Uniwersytetu Warszawskiego, 403.

Napieralski, J., Harbor, J., Li, Y., 2007. Glacial geomorphology and geographic information system. Earth-Science Review, 85: $1-22$.

Narloch, W., Wysota, W., Piotrowski, J.A., 2013. Sedimentological record of subglacial conditions and ice sweet dynamics of the Vistula Ice Stream (north-central Poland) during the Last Glaciation. Sedimentary Geology, 293: 30-44.

Patterson, C.J., 1997. Southern Laurentide ice lobe were created by ice streams: Des Moines lobe in Minnesota, USA. Sedimentary Geology, 111: 249-261.

Patterson, C.J., 1998. Laurentide glacial landscapes: the role of ice streams. Geology, 26: 643-646.

Peterson, W.S.B., 1994. The Physics of Glaciers. Pergamon, Oxford.

Płonczyński, J., Kurek, S., Preidl, M., 2009. Szczegółowa Mapa Geologiczna Polski w skali 1:50 000, ark. Jasionówka (in Polish). Państwowy Instytut Geologiczny, Warszawa.

Przybylski, B., 2008. Geomorphic traces of Wechselian ice stream in the Wielkopolska Lowland, western Poland. Boreas, 37: 286-296.

Punkari, M., 1980. The ice lobes of the Scandinavian ice-sheet during the deglaciation in Finland. Boreas, 9: 307-310.

Punkari, M., 1993. Modelling of the dynamics of the Scandinavian Ice-sheet using remote sensing and GIS methods. In: Glaciotectonics and Mapping Glacial Deposits (ed. J. Aber): 232-250. Proceedings of the INQUA Commission on the Formation and Properties of Glacial Deposits. Canadian Plains Research Center, University of Regina.

Punkari, M., 1995a. Function of the ice streams in the Scandinavian Ice-sheet: analyses of glacial geological data from southwestern Finland. Transactions of the Royal Society of Edinburgh, Earth Sciences, 85: 283-302.

Punkari, M., 1995b. Glacial flow systems in the zone of confluence between the Scandinavian and Novaya Zemyla Ice-sheets. Quaternary Science Reviews, 14: 589-603.

Renssen, H., Kasse, C., Vandenberghe, J., Lorenz, S.J., 2007. Weichselian Late Pleniglacial surface winds over Northwest and 
Central Europe: a model-data comparison. Journal of Quaternary Science, 22: 281-293.

Rychel, J., Karasiewicz, M.T., Krześlak, I., Krzywicki, T., Marks, L., Noryśkiewicz, B., Pochocka-Szwarc, K., Woronko, B., 2012. Peryglacjalne przekształcenie rzeźby Wzgórz Sokólskich w ostatnim okresie zimnym (in Polish). In: Czynniki różnicowania rzeźby Niżu Polskiego (eds. D. Dzieduszyńska and M. Roman): 71-73. Uniejów 13-15 czerwca, 2012. Uniwersytet Łódzki.

Rychel, J., Woronko, B., Karasiewicz, M.T., Szymczuk, M., Morawski, M., 2015. Ice-sheet dynamics of Warta Glaciation (Saale, MIS 6) in the marginal zone around Knyszewicze area. Studia Quaternaria, 32: 79-90.

Stokes, C.R., Clark, C.D., 1999. Geomorphological criteria for identifying Pleistocene ice streams. Annals of Glaciology, 28: 67-75.

Stokes, C.R., Clark, C.D., 2001. Paleo-ice streams. Quaternary Science Reviews, 20: 1437-1457.

Stokes, C.R., Clark, C.D., 2002. Are long subglacial bedforms indicative of fast ice flow? Boreas, 31: 239-249.

Stokes, C.R., Clark, C.D., Storrar, R., 2009. Major changes in ice stream dynamics during deglaciation of the north-western margin of Laurentide Ice Sheet. Quaternary Science Reviews, 28: 721-738.

Szuman, I., Ewertowski, M., Kasprzak, L., 2013. Thermo-mechanical facies representative of fast and slow flowing ice sheets: the Weichselian ice sheet, a central west Poland case study. Proceedings of the Geologists' Association, 124: 818-833.

Tirén, S.A., Beckholmen, M., 1989. Block faulting in southeastern Sweden interpreted from digital terrain models. Geologiska Föreningens i Stockholm Förhandlingar (GFF), 111: 171-179.
Turkowska, K., 2006. Geomorfologia regionu łódzkiego (in Polish). Wydawnictwo Uniwersytetu Łódźkego, Łódź.

Winguth, C., Mickelson, D.M., Colgan, P.M., Laabs, B.J.C., 2004. Modeling the deglaciation of the Green Bay Lobe of the southern Laurentide Ice Sheet. Boreas, 33: 34-47.

Woronko, B., Rychel, J., Karasiewicz, M.T., Kupryjanowicz, M., Adamczyk, A., Fiłoc, M., Marks, L., Krzywicki, T., Pochocka-Szwarc, K., 2017. Post-Saalian transformation of dry valleys in Eastern Europe: an example from NE Poland. Quaternary International; doi: 10.1016/j.quaint.2016.09.054

Wrotek, K., 2009. Szczegółowa Mapa Geologiczna Polski w skali 1:50 000, ark. Dąbrowa Białostocka (in Polish). NAG PIG-PIB, nr. arch. 3413/2009.

Wrotek, K, 2009. Objaśnienia do Szczegółowej mapy geologicznej Polski w skali 1:50 000, arkusz Dąbrowa Białostocka (225) (in Polish). NAG PIG-PIB, nr arch. 3413/2009.

Wysota, W., Molewski, P., 2011. Chronology and extents of ice sheet advances in the Vistula lobe area during the Main Stage of the Last Glaciation (in Polish with English summary). Przegląd Geologiczny, 59: 214-225.

Zeeberg, J.J., 1998. The European sand belt in eastern Europe and comparison of Late Glacial dune orientation with GCM simulation results. Boreas, 27: 127-139.

Zieliński, P., Sokołowski, R.J., Woronko, B., Jankowski, M., Fedorowicz, S., Standzikowski, K., 2016. Sandy deposition in a small dry valley in the periglacial zone of the Last Glacial Maximum: a case study from the Józefów site, SE Poland. Quaternary International, 399: 58-71. 